\title{
Rancang Bangun Aplikasi Tracking Paket Ekspedisi CV MK Express
}

\author{
Siti Juwariyah*, Siti Sufaidah, Moh. Anshori Aris Widya \\ Program Studi Informatika, Fakultas Teknologi Informasi, Universitas KH. A. Wahab Hasbullah \\ Jombang \\ Jl. Garuda No. 09 Tambakberas, Jombang \\ *email: siti.joe27@gmail.com
}

(Naskah masuk: 20 September 2020; diterima untuk diterbitkan: 2 April 2021)

\begin{abstract}
ABSTRAK - Inovasi menjadi salah satu upaya bagi sebuah instansi atau perusahaan untuk terus meningkatkan kualitas pelayanan, hal ini dilakukan agar dapat bertahan di era hiperkompetisi saat ini. CV MK Express adalah perusahaan baru yang bergerak di bidang jasa, yaitu ekspedisi pengiriman barang maupun dokumen. Sebagai perusahaan pendatang, CV MK Express berinovasi dengan cara membuat sebuah aplikasi berbasis mobile. Aplikasi ini meliputi sistem pelacakan, penjemputan dan pengantaran paket yang memanfaatkan fitur GPS (Global Positioning System). Sistem pelacakan paket pada aplikasi ini berbeda dengan aplikasi sejenis karena menggunakan sistem lacak realtime, dimana pengguna dapat melihat titik keberadaan paket per interval waktu yang telah ditentukan sebelumnya. Penelitian ini bertujuan untuk merancang dan membangun aplikasi tersebut dengan basis mobile android. Android pada aplikasi ini berjenis hybrid dan dibangun menggunakan framework7, sedangkan basis data yang digunakan adalah MySQL. Di sisi pelanggan penelitian ini diharapkan dapat memberikan kemudahan dalam melakukan permintaan penjemputan dan pelacakan paket, sedangkan di sisi perusahaan diharapkan dapat memperlancar proses bisnis yang dijalankan.
\end{abstract}

Kata Kunci - android hybrid, ekspedisi, framework7, GPS (Global Positioning System), sistem tracking.

\section{Engineering of Freight Forwarding Tracking Application at CV MK Express}

\begin{abstract}
Innovation is an effort done by an agencies or companies to improve the service quality so that they can survive in the current hypercompetition era. CV MK Express is a new company engaged in the service sector, particularly in the expedition service for goods and documents. As a newcomer company, CV $M K$ Express innovates its service by creating a mobile-based application. This application includes a tracking system, picking-up and delivery of packages using GPS (Global Positioning System) feature. The package tracking system in this application is different from other similar applications because it uses a realtime tracking system, where users can see the presence point of packages per predetermined time interval. This study aims to design and build this application on the basis of mobile android. Android in this application is a hybrid type and was built using framework7, while the database used is MySQL. On the customer side, this research is expected to provide convenience service in making requests to pick-up and track the packages, while on the company side it is expected to expedite the business processes.
\end{abstract}

Keywords - android hybrid, expedition, framework7, GPS (Global Positioning System), tracking system.

\section{Pendahuluan}

Kebutuhan dalam memperoleh informasi semakin meningkat seiring berkembangnya teknologi di bidang informasi. Informasi yang dihasilkan harus lebih cepat dan akurat agar 
dapat dimanfaatkan sebagai acuan dalam peningkatan kinerja, pelayanan dan kualitas dalam sebuah perusahaan atau organisasi.

CV MK Express adalah salah satu perusahaan yang bergerak di bidang jasa, yaitu pengiriman barang maupun dokumen. Perusahaan ini merupakan perusahaan baru sehingga membutuhkan sebuah sistem untuk menjalankan usahanya. Sebagai perusahaan pendatang, CV MK Express harus mempunyai inovasi pelayanan agar dapat bersaing dengan perusahaan sejenis yang telah ada sebelumnya, inovasi inilah yang akan diimplementasikan ke sebuah sistem. Sistem meliputi sistem pengiriman, sistem pelacakan, sistem penjemputan, dan sistem pengantaran. Sistem-sistem tersebut dapat dipermudah dengan adanya sebuah aplikasi berbasis mobile.

Salah satu sistem operasi pada platform mobile yang popular di Indonesia adalah Android. Berdasarkan data statistik penjualan smartphone berdasarkan platform yang didapat dari situs InovasiPintar.com dari tahun 2010 s.d. 2015, jumlah penjualan smartphone android naik tiap tahunnya mendekati angka 180.000 unit, pada tahun 2015 mencapai jumlah tertinggi jika dibandingkan dengan platform lain seperti symbian, apple, dan windows mobile. [1]

Menurut Nazruddin Safaat (2011), android adalah sebuah sistem operasi untuk perangkat mobile berbasis linux yang mencakup sistem operasi middleware dan aplikasi. Android menyediakan platform terbuka bagi para pengembang untuk menciptakan sebuah aplikasi. Pada awalnya Google Inc. membeli Android Inc. yang merupakan pendatang baru yang membuat piranti lunak untuk ponsel (smartphone). Kemudian untuk mengembangkan Android, dibentuklah Open Handset Alliance, konsorsium dari 34 perusahaan piranti keras, piranti lunak, dan telekomunikasi, termasuk Google, HTC, Intel, Motorola, Qualcomm, TMobile, dan Nvidia. [2]

Aplikasi mobile secara garis besar terbagi menjadi tiga kategori yaitu aplikasi native, aplikasi hybrid, dan aplikasi mobile web. Masingmasing kategori memiliki karakteristik yang berbeda antara satu dengan lainnya.

Aplikasi native memiliki karakteristik terkait dengan single platform. Dalam pengembangan aplikasi diturunkan dari suatu platform perangkat mobile seperti android atau IOS. Pembuatan program aplikasi native ditulis dengan menggunakan platform SDK misalnya android SDK. Ketika akan mengembangkan aplikasi mobile yang berjalan pada beberapa platform maka setiap program harus ditulis pada masing-masing platform tersebut. Aplikasi native dapat mengakses ke semua native API (Application Programming Interface). API ini yang memungkinkan aplikasi dapat dimanfaatkan pihak lain walaupun berbeda platform[3]. Aplikasi native juga memiliki performa grafik yang cepat. Setelah pembuatan aplikasi selesai dilakukan dan akan didistribusikan, pendistribusiannya dapat dilakukan melalui appstore (marketplace) yang mendukung platform tersebut.

Kategori yang kedua adalah aplikasi hybrid. Berbeda dengan aplikasi native, aplikasi hybrid diciptakan berkaitan dengan cross platform. Aplikasi ini ditulis dengan menggunakan teknologi web seperti html 5, CSS3, atau dengan javascript. Aplikasi di sini dapat berjalan pada suatu perangkat dan mendukung aplikasi offline.

Kategori ketiga dari aplikasi mobile adalah jenis aplikasi mobile web. Aplikasi ini diciptakan dari dukungan cross platform. Aplikasi ini ditulis dengan teknologi web seperti HTML, CSS, Javascript, atau server side seperti PHP, ASP.net dan lainnya. Aplikasi mobile web dijalankan pada sisi server dan dapat ditampilkan pada berbagai perangkat. Update data pada aplikasi ini dilakukan secara tersentral atau terpusat. [4]

Aplikasi yang akan dibuat pada penelitian ini menggunakan Framework7. Framework7 adalah kerangka kerja seluler HTML sumber terbuka dan gratis untuk mengembangkan aplikasi seluler hibrida atau aplikasi web dengan tampilan dan nuansa asli iOS atau Android (material). Ini juga alat aplikasi prototyping yang sangat diperlukan untuk menunjukkan prototipe aplikasi kerja sesegera mungkin jika diperlukan. Framework7 dibuat oleh Vladimir Kharlampidi. [5]

Menurut A. Kupper, U. Bareth and B. Freese (2011) penggunaan GPS akan membantu menemukan letak koordinat latitude dan longitude dari target. GPS yang digunakan akan memanfaatkan GPS dapat menginformasikan letak secara global. [6] GPS menggunakan sistm navigasi satelit sebanyak 24 satelit.[7] GPS yang terdapat pada smartphone yang akan diaktifkan pada saat target di jalan. Perkembangan penelitian lebih lanjut dapat menggunakan GPS tracker khusus yang dapat dipasang di kendaraan. Koordinat dari GPS nantinya akan dikirimkan ke server untuk membantu mendeteksi geofencing. [8]

Pada penelitian sebelumnya yang berjudul 
Pemodelan Prototype Tracking Dengan Pemanfaatan Geolocation sebagai GPS (Global Positioning System) Berbasis Web Mobile pada Jasa Pengiriman JNE Semarang pada jurnal ilmiah Techno.COM, Februari 2016, penelitian tersebut menghasilkan Pemodelan Prototype Tracking dengan Pemanfaatan Geolocation sebagai GPS dapat dimanfaatkan sebagai media dalam memonitor pengiriman barang secara visual (map). Pada penelitian ini pelanggan sisi pengirim belum mempunyai akun tersendiri sehingga apabila ingin melakukan cek pengiriman barang harus menginputkan kode pengiriman. Sedangkan pada penelitian yang akan dilakukan, sisi pengirim dapat melakukan cek pengiriman di menu histori pengiriman tanpa harus memasukkan kode pengiriman. [9]

Penelitian terdahulu kedua berjudul Perancangan Alat Untuk Tracking Ekspedisi Berbasis GPS (Google Maps) via SMS pada jurnal ICT Akademi Telkom Jakarta November 2018, pada penelitian ini metode penentuan posisi pada penelitian ini menggunakan metode point positioning (metode absolut), dimana penentuan posisi hanya berdasarkan satu penerima. Sistem yang dibuat pada penelitian ini memanfaatkan modul GPS yang dipasang di kendaraan driver dan laporan dikirimkan via SMS, sedangkan pada penelitian yang akan dilakukan memanfaatkan fitur GPS yang ada di ponsel android kurir. [10]

Penelitian terdahulu yang lain berjudul Rancang Bangun Aplikasi Jasa Pengiriman Paket Online Berbasis Android Pada PT Pos Indonesia pada jurnal JSIKA, Vol. 6, No 8 (2017). Aplikasi yang dihasilkan pada penelitian ini dapat memberikan layanan seperti, data pelanggan layanan pos, pengolahan data agen pos, pengolahan transaksi pengiriman, pencatatan pengiriman, dan pembayaran. Pada penelitian ini pelanggan sisi pengirim sudah mempunyai akun tersendiri namun apabila ingin melakukan cek pengiriman barang harus menginputkan kode pengiriman. Sedangkan pada penelitian yang akan dilakukan, sisi pengirim dapat melakaukan cek pengiriman di menu histori pengiriman tanpa harus memasukkan kode pengiriman. [11]

Mekanisme sistem pada penelitian ini berdasarkan Standar Operasional Prosedur (SOP) CV MK Express. Pengguna pada penelitian ini terdiri dari kurir dan pelanggan, untuk kurir aplikasi digunakan untuk penjemputan dan pengantaran barang, sedangkan untuk pelanggan digunakan untuk melakukan permintaan penjemputan barang dan pelacakan barang yang dikirim. Tracking ini diperlukan karena termasuk ke dalam salah satu dimensi utama dari kualitas layanan ekspedisi.[12]

\section{METODE DAN BAHAN}

Penelitian ini dilakukan melalui beberapa tahapan. Adapun metode yang digunakan dalam tiap-tiap tahapan ditunjukkan gambar 1.

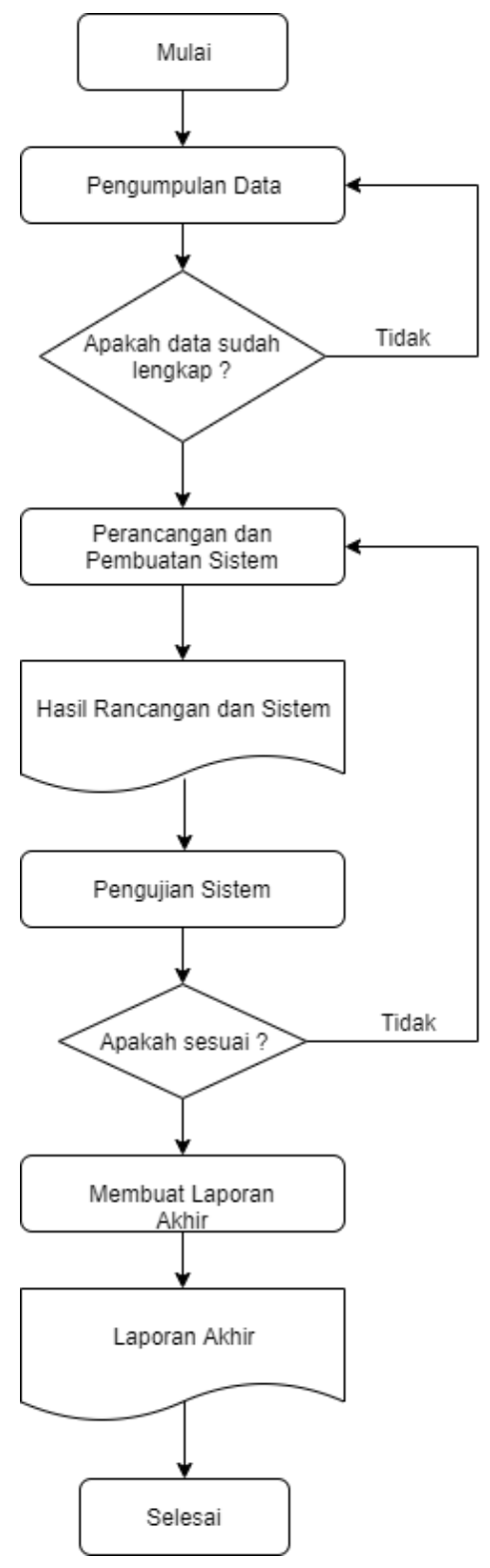

Gambar 1 Flowchart Alur Penelitian

\section{Metode Pengumpulan Data}

Pengumpulan data yang dilakukan melalui beberapa cara yaitu : studi pustaka, wawancara, 
dan observasi lapangan atau pengamatan secara langsung.

a. Studi Pustaka

Metode ini dilakukan dengan cara mengumpulkan beberapa data terkait bahasan pada penelitian, data-data tersebut diambil dari sumber-sumber relevan seperti buku, jurnal nasional dan internasional.

b. Wawancara

Wawancara dilakukan dengan pihak yang terkait yaitu pemilik CV MK Express. Dilakukan dengan cara memberikan beberapa pertanyaan untuk dapat mengetahui masalah yang dihadapi sehingga lebih mudah untuk mencari solusi terhadap masalah tersebut.

c. Observasi Lapangan

Pada tahapan observasi peneliti melakukan beberapa observasi pada tempat dan sumber yang menjadi fokus penelitian.

\section{Metode Perancangan Sistem}

Perangkat lunak dalam penelitian ini dibangun dengan menggunakan metode prototype dengan tahapan sebagai berikut:

a. Analisa Kebutuhan

Analisa kebutuhan dilakukan dengan menggali informasi apa saja yang dibutuhkan pihak CV MK Express agar sistem yang dibuat nantinya sesuai dengan yang dibutuhkan.

b. Desain Sistem

Desain sistem dilakukan dengan menggunakan UML yang terdiri dari Use Case, Activity Diagram, Sequence Diagram, dan Class Diagram. Realisasi dari class diagram berupa database. Perancangan user interface nya menggunakan mockups.

c. Membangun Prototype

Pembangunan Prototype sistem menggunakan metode pengembangan prototyping, bahasa pemrograman PHP dan database MySQL.

d. Evaluasi dan Perbaikan

Setelah implementasi dilakukan tahapan testing menggunakan metode BlackBox.

\section{Analisa Sistem Berjalan}

Pelayanan jasa ekspedisi yang dilakukan oleh CV MK Express saat ini sesuai dengan Standar Operasional Prosedur yang telah ada. Pelanggan yang ingin mengirimkan barangnya harus datang ke kantor CV MK Express, bagian admin akan menginput identitas paket yang akan dikirimkan, setelah didata oleh operator kemudian dilakukan pencetakan resi dan label pengiriman barang, resi diberikan kepada pelanggan sedangkan label pengiriman ditempel ke barang. Selanjutnya barang akan dikirimkan sesuai antrian. Sebagai gambaran mengenai sistem yang berjalan ditunjukkan gambar 2.

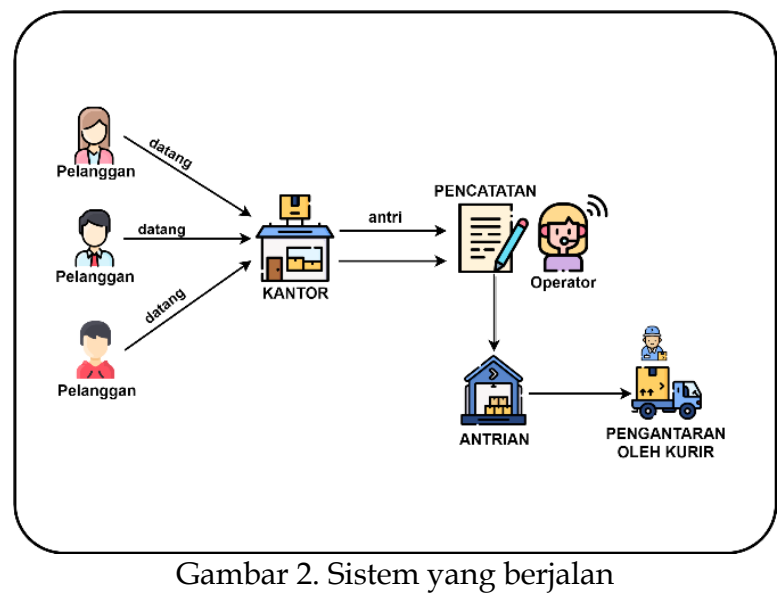

\section{Analisis Sistem yang Diusulkan}

Berdasarkan pada analisis sistem yang berjalan, untuk mengatasi masalah-masalah yang ada pada basis data, sistem pengarsipan dan pelaporan, pelacakan paket dan layanan pickup (jemput barang), maka diusulkan sebuah aplikasi tracking paket berbasis android.

Dengan dibuatnya sistem ini diharapkan dapat membantu dalam pelacakan paket dan layanan pick up (jemput barang). Jika pelanggan dapat melakukan transaksi tanpa harus antre dengan memanfaatkan fitur pick up, untuk pelacakan dapat memanfaatkan fitur lacak paket realtime. Untuk lebih jelasnya mengenai sistem yang diusulkan ditunjukkan gambar 3 . 


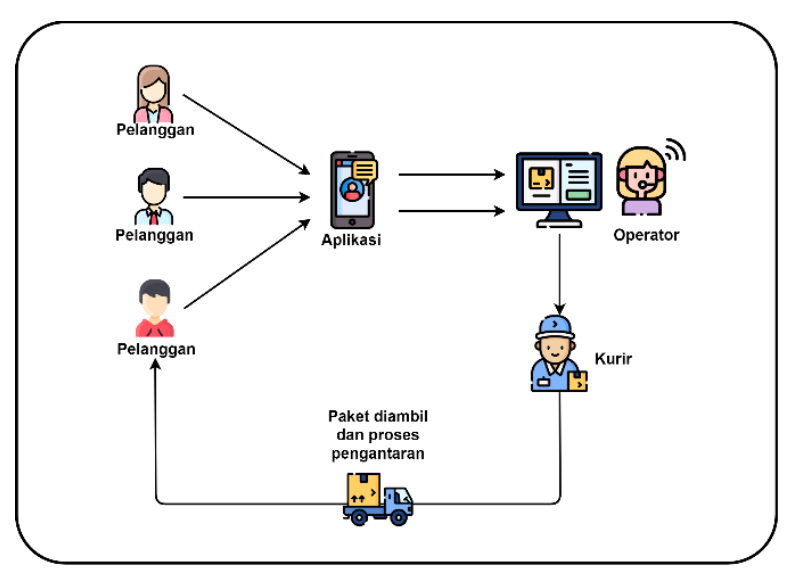

Gambar 3 Sistem yang diusulkan

\section{Analisa Kebutuhan Fungsional}

Kebutuhan fungsional merupakan kebutuhan yang berisi proses-proses yang nantinya dapat dilakukan oleh sistem, untuk lebih jelasnya dapat dilihat pada tabel 1 .

Tabel 1 Kebutuhan Fungsional

\begin{tabular}{|c|c|}
\hline User & Hak Akses \\
\hline \multirow[t]{7}{*}{ Pelanggan } & $\begin{array}{l}\text { 1. Melakukan pendaftaran } \\
\text { akun }\end{array}$ \\
\hline & 2. Melakukan Login \\
\hline & $\begin{array}{l}\text { 3. Melakukan update data } \\
\text { akun }\end{array}$ \\
\hline & 4. Melakukan lacak paket \\
\hline & $\begin{array}{l}\text { 5. Melakukan cek ongkos } \\
\text { kirim }\end{array}$ \\
\hline & $\begin{array}{l}\text { 6. Melakukan transaksi Pick } \\
\text { up }\end{array}$ \\
\hline & $\begin{array}{l}\text { 7. Melihat history } \\
\text { pengiriman }\end{array}$ \\
\hline \multirow[t]{8}{*}{ Kurir } & 1. Melakukan Login \\
\hline & 2. Melakukan lacak paket \\
\hline & $\begin{array}{l}\text { 3. Melakukan cek ongkos } \\
\text { kirim }\end{array}$ \\
\hline & $\begin{array}{l}\text { 4. Approval transaksi Pick } \\
\text { up }\end{array}$ \\
\hline & 5. Melakukan input transaksi \\
\hline & $\begin{array}{l}\text { 6. Mencetak resi setelah } \\
\text { melakukan transaksi Pick } \\
\text { up }\end{array}$ \\
\hline & $\begin{array}{l}\text { 7. Melihat delivery draft } \\
\text { (daftar pengantaran } \\
\text { barang) }\end{array}$ \\
\hline & $\begin{array}{l}\text { 8. Melihat history } \\
\text { pengantaran barang }\end{array}$ \\
\hline
\end{tabular}

Kebutuhan fungsional dapat dikelompokakan menjadi 3, yaitu kebutuhan input, kebutuhan proses, dan kebutuhan output. Kebutuhankebutuhan ini secara berurutan ditunjukkan pada Tabel 2, Tabel 3, dan Tabel 4.

Tabel 2 Kebutuhan Input

\begin{tabular}{|c|c|c|}
\hline No. & Jenis & Keterangan \\
\hline 1. & $\begin{array}{l}\text { Data } \\
\text { Pelanggan }\end{array}$ & $\begin{array}{l}\text { Digunakan untuk } \\
\text { perancangan tabel } \\
\text { pelanggan }\end{array}$ \\
\hline 2. & Data Kurir & $\begin{array}{l}\text { Digunakan untuk } \\
\text { perancangan tabel } \\
\text { kurir }\end{array}$ \\
\hline 3. & $\begin{array}{l}\text { Data Jenis } \\
\text { Barang }\end{array}$ & $\begin{array}{l}\text { Digunakan untuk } \\
\text { perancangan tabel } \\
\text { barang }\end{array}$ \\
\hline 4. & $\begin{array}{l}\text { Data } \\
\text { Pengiriman }\end{array}$ & $\begin{array}{l}\text { Digunakan untuk } \\
\text { perancangan tabel } \\
\text { alamat }\end{array}$ \\
\hline 5. & $\begin{array}{l}\text { Data } \\
\text { Wilayah }\end{array}$ & $\begin{array}{l}\text { Digunakan untuk } \\
\text { perancangan tabel } \\
\text { desa, kecamatan, } \\
\text { kabupaten dan } \\
\text { propinsi }\end{array}$ \\
\hline 6. & Data Harga & $\begin{array}{l}\text { Digunakan untuk } \\
\text { perancangan tabel } \\
\text { harga }\end{array}$ \\
\hline
\end{tabular}

Tabel 3 Kebutuhan Proses

\begin{tabular}{|c|c|c|}
\hline No. & Jenis & Keterangan \\
\hline 1. & $\begin{array}{l}\text { Pendaftaran } \\
\text { Member }\end{array}$ & $\begin{array}{l}\text { Digunakan untuk } \\
\text { mendaftar sebagai } \\
\text { member }\end{array}$ \\
\hline 2. & $\begin{array}{l}\text { Permintaan pick } \\
\text { up }\end{array}$ & $\begin{array}{l}\text { Digunakan untuk } \\
\text { permintaan pick up } \\
\text { paket yang akan } \\
\text { dikirimkan }\end{array}$ \\
\hline 3. & $\begin{array}{l}\text { Approval pick } \\
\text { up }\end{array}$ & $\begin{array}{l}\text { Digunakan untuk } \\
\text { approval permintaan } \\
\text { pick up }\end{array}$ \\
\hline 4. & $\begin{array}{l}\text { On the spot } \\
\text { transaction }\end{array}$ & $\begin{array}{l}\text { Digunakan untuk } \\
\text { input data } \\
\text { pengiriman di } \\
\text { tempat }\end{array}$ \\
\hline 5. & $\begin{array}{l}\text { Permintaan cek } \\
\text { harga }\end{array}$ & $\begin{array}{l}\text { Digunakan untuk } \\
\text { mengecek harga }\end{array}$ \\
\hline
\end{tabular}

Tabel 4 Kebutuhan Output

\begin{tabular}{cll}
\hline No. & \multicolumn{1}{c}{ Jenis } & \multicolumn{1}{c}{ Keterangan } \\
\hline 1. & Label & Label untuk \\
& Pengiriman & pengiriman
\end{tabular}




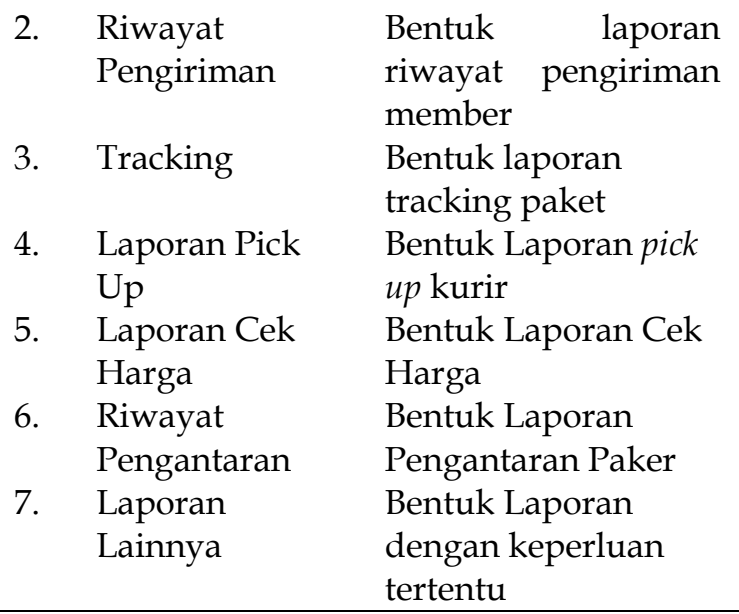

\section{HASIL DAN PEMBAHASAN}

\section{Use Case Diagram}

Use case Diagram menangkap perilaku yang dibutuhkan dan dikehendaki dari suatu sistem (subsistem, kelas, atau antarmuka) yang akan dikembangkan tanpa menspesifikasikan bagaimana perilaku itu akan diimplementasikan. Dalam kasus ini, pada dasarnya use case merupakan interaksi khusus antara para aktor dan sistem untuk menangkap sasaran serta kebutuhan para aktor (User needs and expectation) [13]. Use Case Diagram akan dijabarkan secara detail pada gambar berikut:

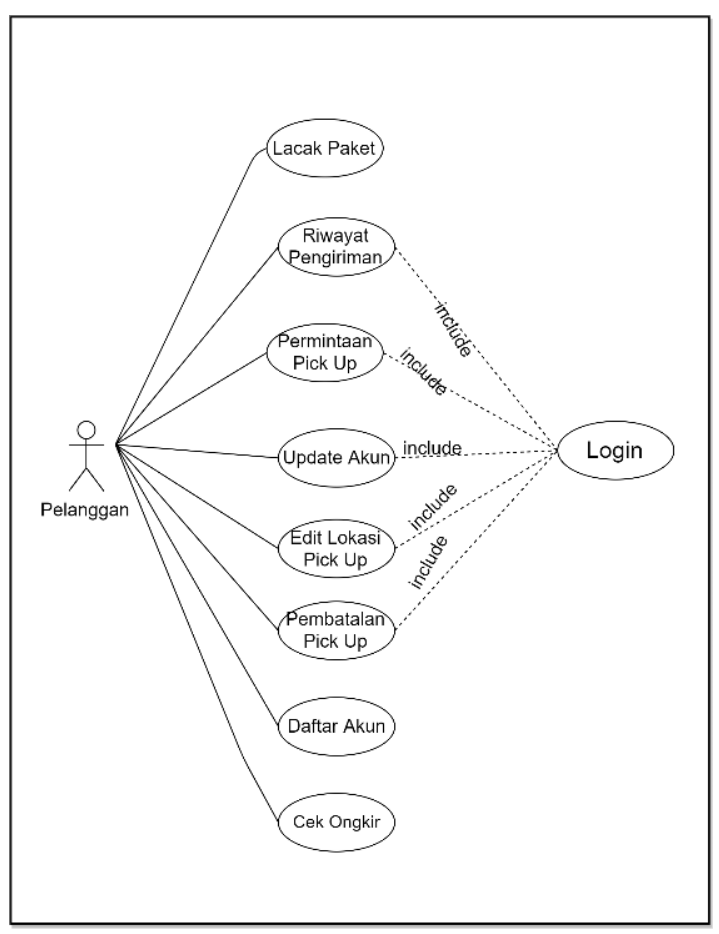

Gambar 4 Use Case Diagram Pelanggan

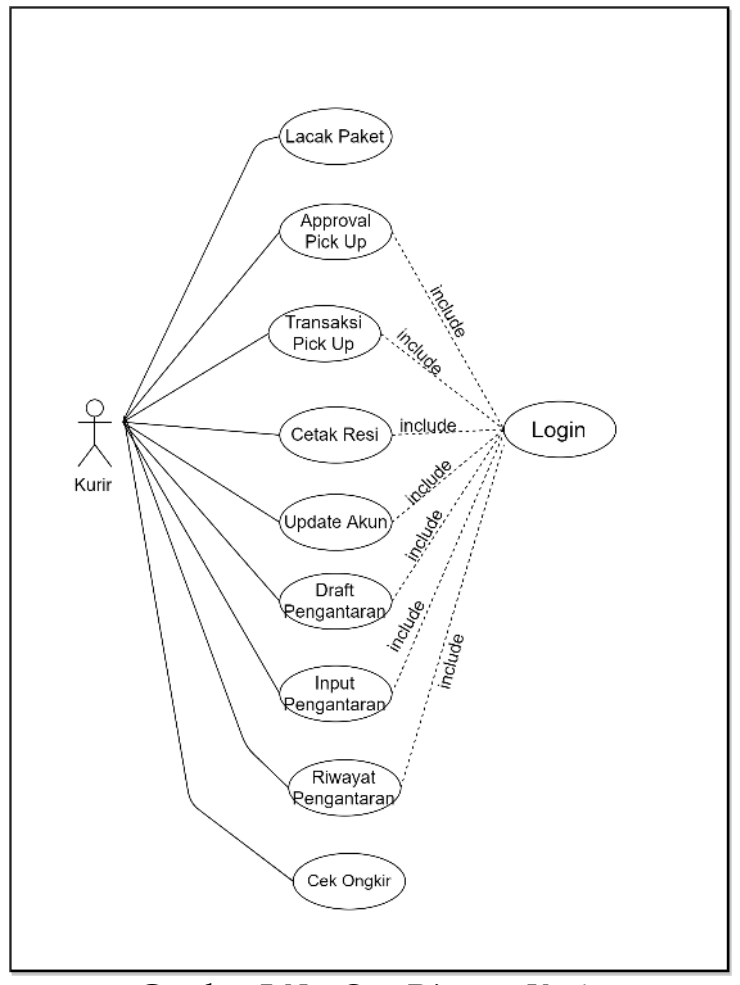

Gambar 5 Use Case Diagram Kurir

Sedangkan penjelasan dari Gambar Use Case Diagram bisa dilihat pada tabel 5 .

Tabel 5 Pemodelan Use Case

\begin{tabular}{ll}
\hline Aktor & \multicolumn{2}{c}{ Keterangan } \\
\hline Pelanggan & Pelanggan mempunyai kegiatan \\
& yaitu daftar akun, login, cek \\
& ongkir, lacak paket, melakukan \\
& permintaan pick up, melihat \\
& riwayat pengiriman dan \\
& melakukan perubahan data \\
& (update) akun pelanggan. Untuk \\
& kegiatan permintaan pick up, \\
& melihat riwayat pengiriman dan \\
& melakukan perubahan data \\
& (update) akun, pelanggan harus \\
& login terlebih dahulu. \\
& Kurir mempunyai kegiatan yaitu \\
& login, cek ongkir, melakukan \\
& approval pick up, input transaksi \\
& saat pick up, cetak resi \\
& pengiriman, melihat draft \\
& delivery (pengantaran) dan input \\
& data pengantaran untuk \\
& dilaporkan ke server. Seluruh \\
& kegiatan dapat dilakukan ketika \\
& kurir sudah melakukan login. \\
\hline
\end{tabular}




\section{Activity Diagram}

Activity Diagram digunakan untuk memodelkan aspek dinamis dari sistem. Diagram ini berfungsi memodelkan alur kerja (work flow) sebuah proses bisnis dan urutan aktivitas pada suatu proses. Activity Diagram dibuat untuk menggambarkan aktivitas aktor. Activity Diagram untuk penelitian ini adalah sebagai berikut:

a. Permintaan Pick Up Pelanggan

Activity Diagram ini menggambarkan aktivitas aktor pelanggan saat melakukan permintaan penjemputan paket, pelanggan harus mengisi beberapa inputan. Setelah diisi lengkap data akan dikirimkan ke server. Activity Diagram untuk Permintaan Pick Up Pelanggan ditunjukkan gambar 6.

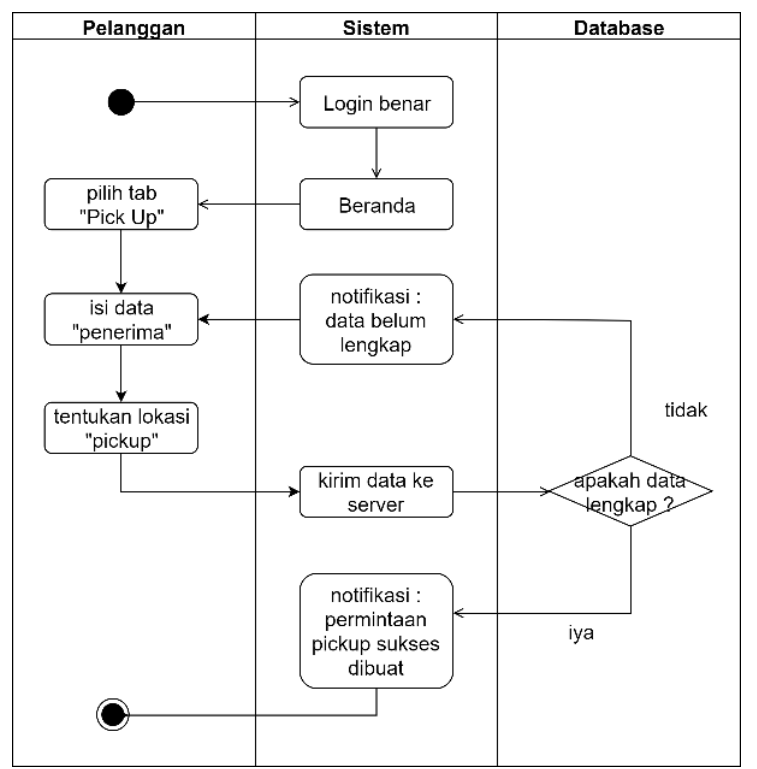

Gambar 6 Activity Diagram Permintaan Pickup

\section{b. History Pengiriman Pelanggan}

Activity Diagram untuk History Pengiriman Pelanggan ini menggambarkan aktivitas aktor pelanggan saat melakukan pengecekan riwayat pengiriman yang pernah dilakukan. Pada fitur ini pelanggan dapat memilih data riwayat pengiriman, baik data paket yang sedang menunggu diproses data paket dalam proses pengiriman dan juga paket yang telah selesai diproses dengan memilih tabulasi yang disediakan. Activity Diagram untuk History Pengiriman Pelanggan ditunjukkan gambar 7.

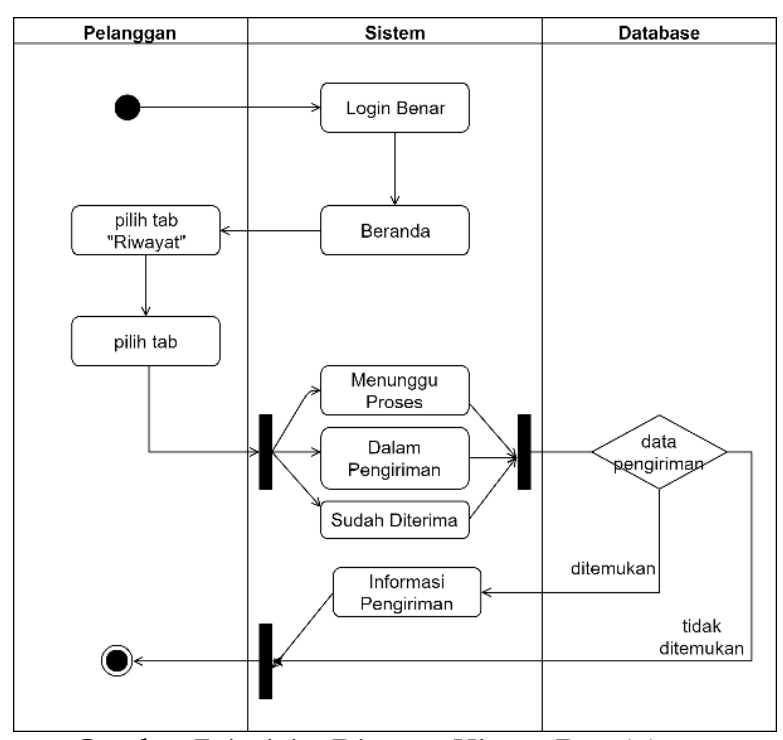

Gambar 7 Activity Diagram History Pengiriman Pelanggan

\section{c. Approval Pick Up Kurir}

Activity Diagram untuk Approval Pick Up Kurir ini menggambarkan aktivitas aktor kurir saat menerima notifikasi pick up, kurir diberi kesempatan untuk menerima atau tidak menerima permintaan pick up yang dikirimkan oleh server, jika kurir menerima permintaan tersebut, maka kurir harus melakukan update data pengiriman yang telah dikirim oleh server untuk selanjutnya dapat mencetak resi pengiriman. Activity Diagram untuk Approval Pick Up Kurir ditunjukkan gambar 8.

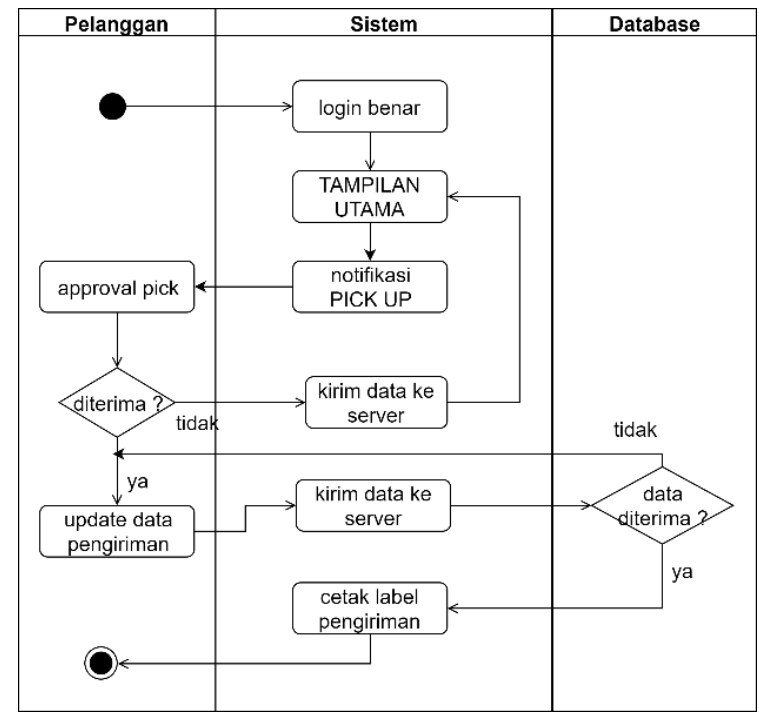

Gambar 8 Activity Diagram Approval Pickup

\section{d. History Pengantaran Kurir}

Activity Diagram untuk History Pengantaran Kurir menggambarkan aktivitas aktor kurir saat 
melakukan pengecekan riwayat pengiriman yang pernah dilakukan.Riwayat yang bisa dilihat ada 2 macam yaitu draft pengantaran dan pengantaran selesai. Activity Diagram untuk History Pengantaran Kurir ditunjukkan gambar 9.

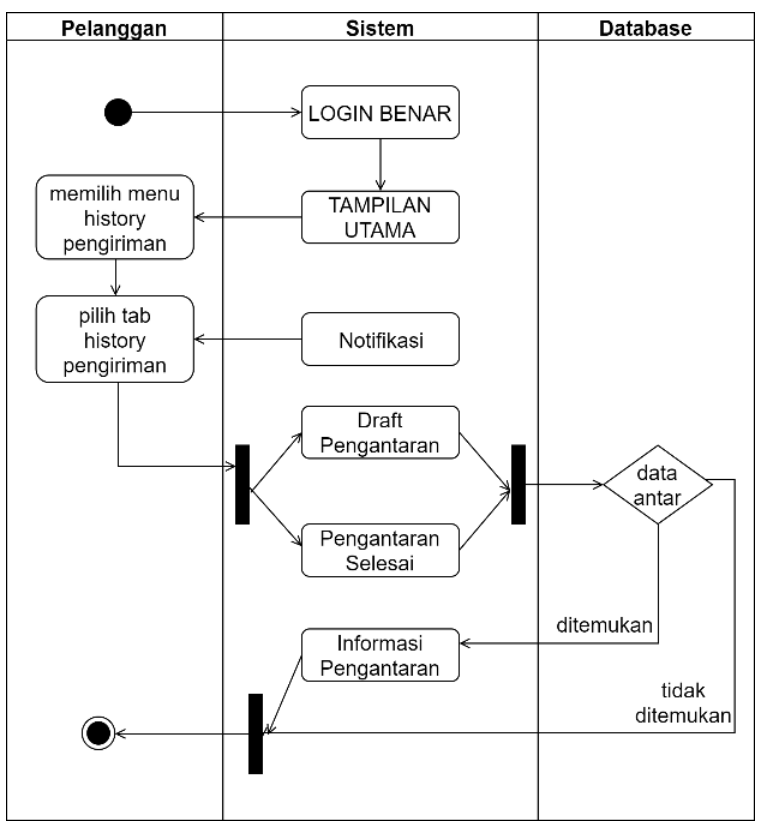

Gambar 9 Activity Diagram History Pengantaran Kurir

\section{Sequence Diagram}

Menurut Haviluddin (2011) Secara mudahnya sequence diagram adalah gambaran tahap demi tahap, termasuk kronologi (urutan) perubahan secara logis yang seharusnya dilakukan untuk menghasilkan sesuatu sesuai dengan use case diagram [14]. Sequence Diagram untuk penelitian ini ditunjukkan gambar 10, 11, 12 dan 13.

a. Pick Up Pelanggan

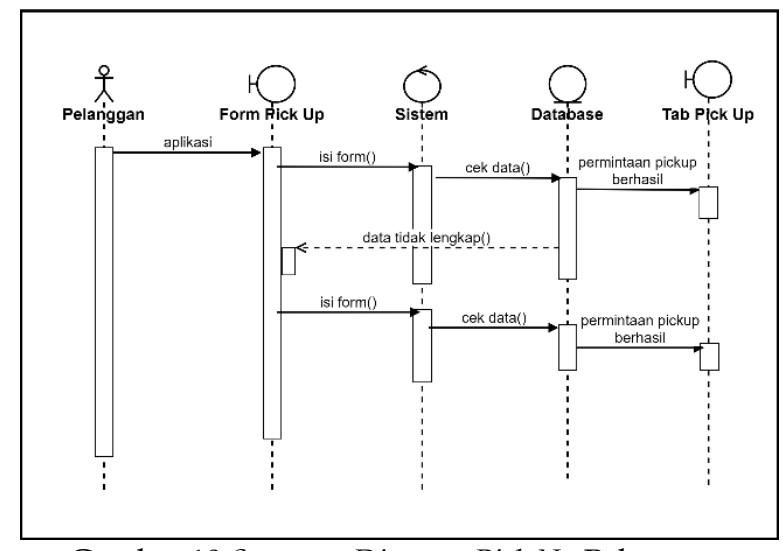

Gambar 10 Sequence Diagram Pick Up Pelanggan b. History Pengiriman Pelanggan

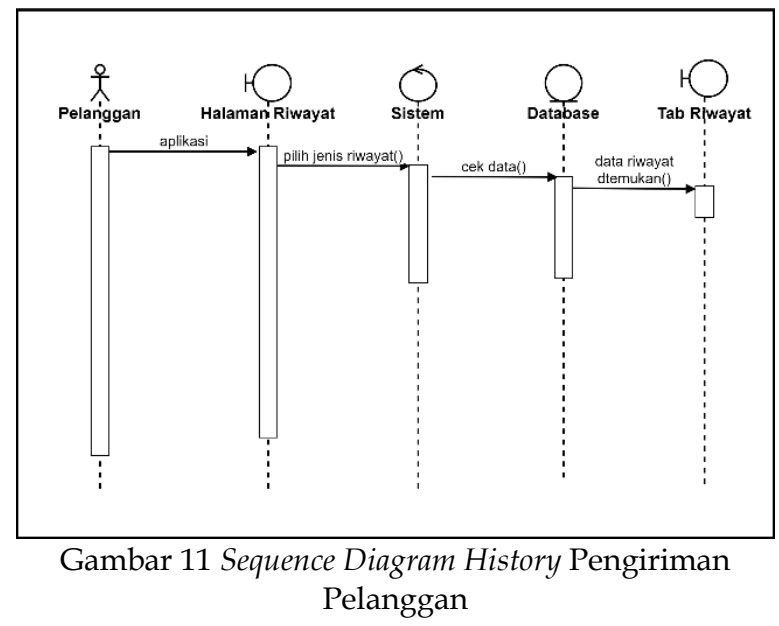

c. Approval Pick Up

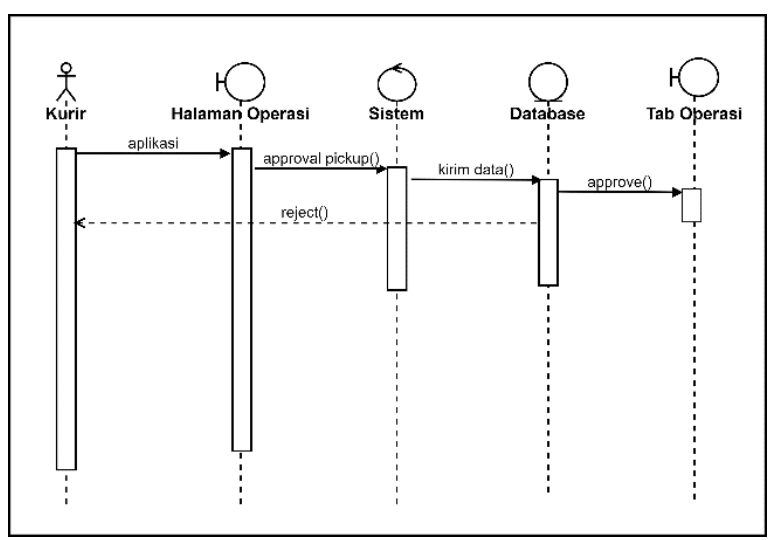

Gambar 12 Sequence Diagram Approval Pick Up

d. History Pengantaran Kurir

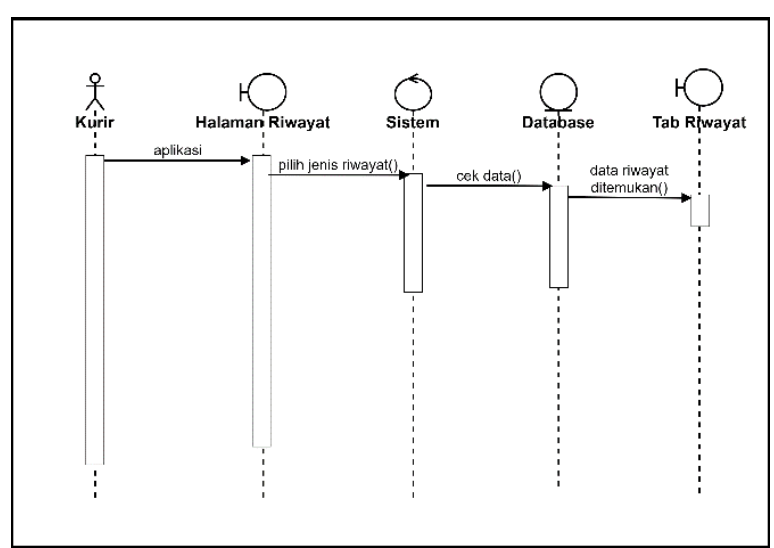

Gambar 13 Sequence Diagram History Pengantaran Kurir

\section{Class Diagram}

Class Diagram digunakan untuk pemodelan pada basis data. Pemodelan nya terdiri dari kelaskelas yang saling berelasi serta terdiri dari atribut 
dan method. Class Diagram pada penelitian ini ditunjukkan gambar 14.

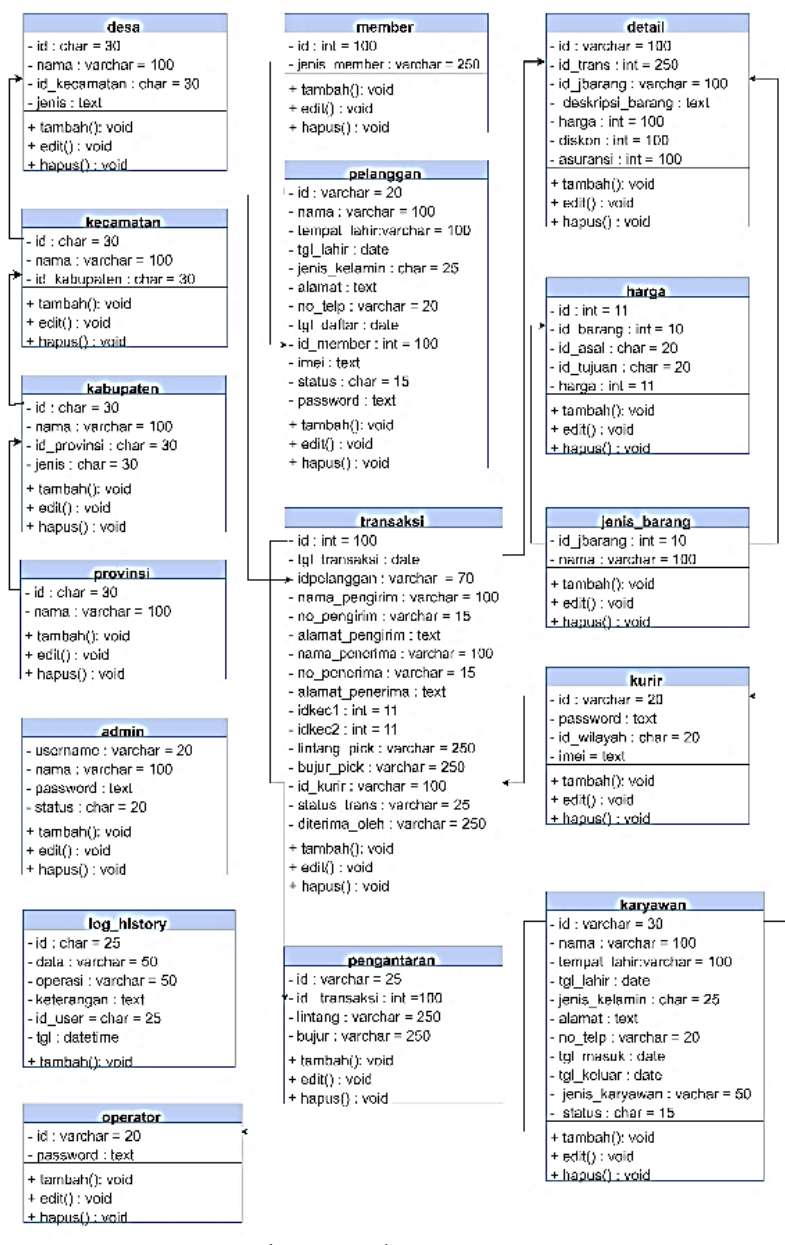

Gambar 14 Class Diagram

\section{Implementasi}

Setelah sistem dianalisis dan didesain secara terperinci maka langkah berikutnya adalah melakukan tahapan implementasi. Tahapan ini bertujuan untuk meletakkan sistem sehingga siap untuk dioperasionalkan, dengan begitu pengguna dapat memberikan masukan atau saran untuk pengembangan sistem di masa depan.

\section{Batasan Implementasi}

Untuk memudahkan tahapan implementasi, maka ada beberapa batasan yang harus terpenuhi. Batasan-batasan tersebut antara lain:

a. Sistem ini dibangun menggunakan bahasa pemograman Java Script dan didukung oleh Bahasa pemrograman PHP untuk APInya.

b. Basis datanya menggunakan MySQL

c. Tools yang digunakan Antara lain: sublime, usbserver, google chrome

\section{Kebutuhan Perangkat Keras}

Perangkat keras yang digunakan selama proses pembangunan Aplikasi Tracking Paket Ekspedisi CV MK Express dapat dilihat pada tabel 6 .

Tabel 6 Kebutuhan Perangkat Keras

\begin{tabular}{cll}
\hline No. & Perangkat Keras & \multicolumn{1}{c}{ Spesifikasi } \\
\hline 1. & Processor & Intel(R) Core(TM) i5- \\
& & $6200 \mathrm{U}$ CPU @ 2.3GHz \\
& & $2.40 \mathrm{GHz}$ \\
2. & RAM & $8 \mathrm{~GB}$ \\
3. & Hardisk & $1 \mathrm{~TB}$ \\
4. & SSD & $256 \mathrm{~GB}$ \\
\hline
\end{tabular}

\section{Kebutuhan Perangkat Lunak}

Komponen perangkat lunak yang digunakan selama proses pembangunan Aplikasi Tracking Paket Ekspedisi CV MK EXPRESS yang dapat dilihat pada tabel 7 .

Tabel 7 Kebutuhan Perangkat Lunak

\begin{tabular}{cll}
\hline No. & $\begin{array}{c}\text { Perangkat } \\
\text { Lunak }\end{array}$ & \multicolumn{1}{c}{ Spesifikasi } \\
\hline 1. & Sistem Operasi & $\begin{array}{l}\text { Microsoft Windows Pro } \\
\text { 10 }\end{array}$ \\
2. & Web Server & USB Webserver \\
3. & Database & MySQL Versi server: \\
& & 5.6.34 \\
4. & Bahasa & Java Script \\
& Pemrograman & \\
5. & API & PHP \\
6. & Browser & Google Chrome \\
\hline
\end{tabular}

\section{Implementasi Interface}

Interface aplikasiditunjukkan pada gambar 14, 15, 16 dan 17. 
a. Halaman Pick Up Pelanggan

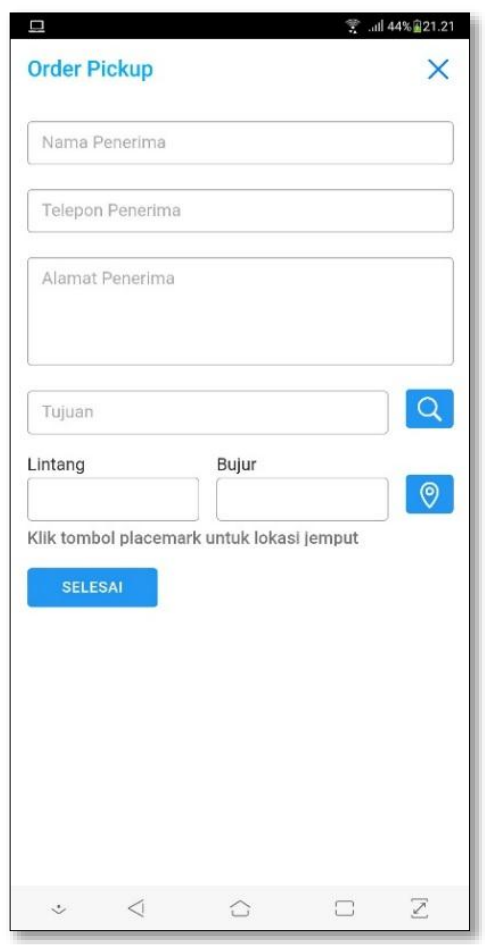

Gambar 15 Halaman Pick Up

b. Halaman Riwayat Pengiriman

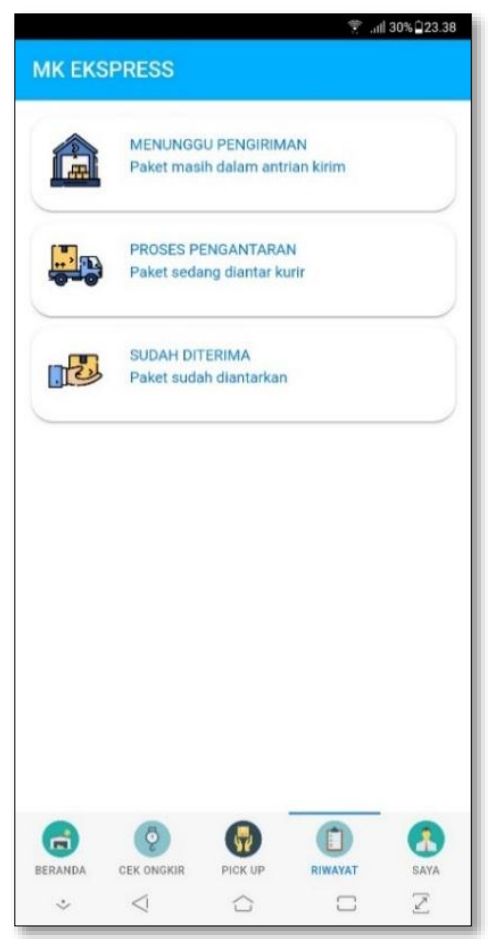

Gambar 16 Halaman Riwayat Pengiriman c. Halaman Approval Pick Up

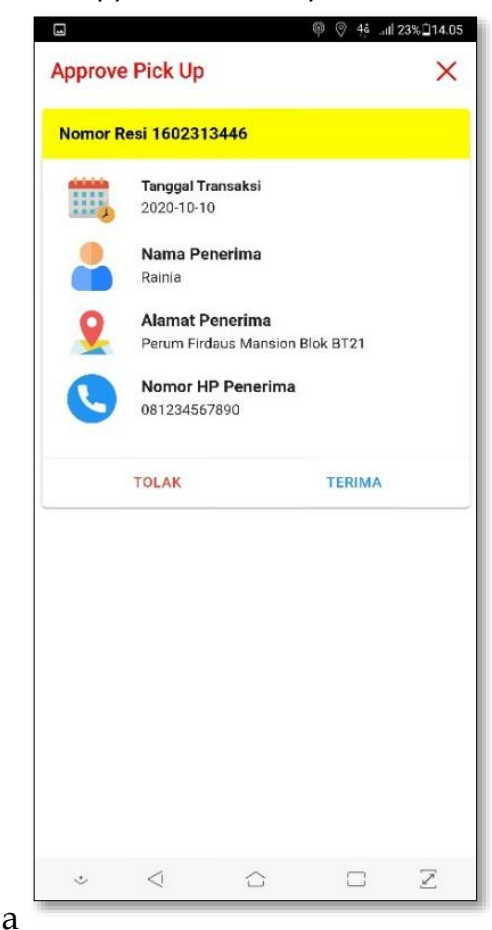

Gambar 17 Halaman Approval Pick Up Kurir

d. Halaman Riwayat Pengantaran Kurir

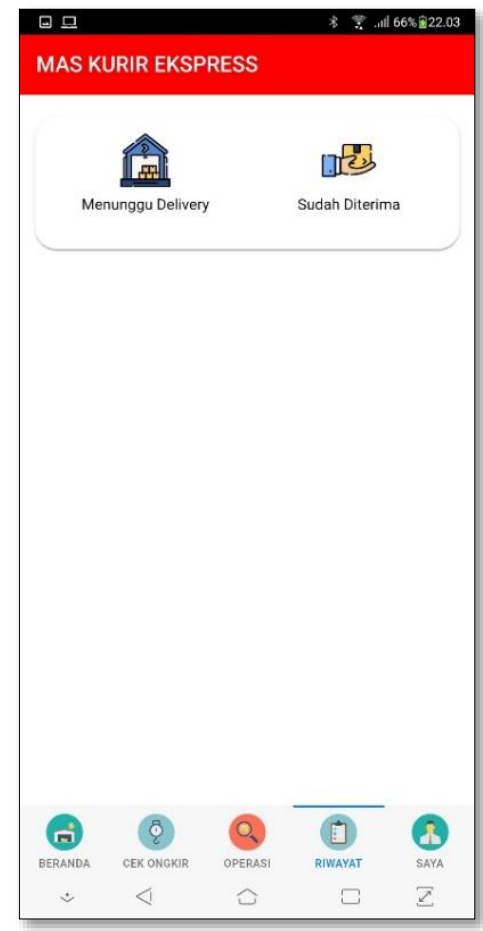

Gambar 18 Halaman Riwayat Pengantaran

\section{PEMBAHASAN}

Dalam tahapan ini akan dibahas mengenai pengujian aplikasi. Pengujian aplikasi ini dimaksudkan untuk mengetahui pengoperasian 
sistem Aplikasi Tracking Paket Ekspedisi CV MK Express yang telah dibuat secara detail dan menyeluruh. Pengujian ini juga bertujuan untuk mencari kesalahan yang mungkin terjadi dan tidak diketahui pada saat pembuatan.

\section{Pengujian Aplikasi}

Pengujian program ini menggunakan metode blackbox. Williams (2010) menyatakan pengujian blackbox atau disebut uji fungsional adalah pengujian yang mengabaikan mekanisme internal sistem atau komponen dan hanya berfokus pada output yang dihasilkan dalam menanggapi input yang dipilih dan kondisi eksekusi. Sehingga dapat disimpukan bahwa blackbox testing merupakan pengujian yang berorientasi pada fungsionalitas yaitu perilaku dari perangkat lunak atas input yang diberikan pengguna sehingga mendapatkan/ menghasilkan output yang diinginkan tanpa melihat proses internal atau kode program yang dieksekusi oleh perangkat lunak[15].

Pengujian dilakukan dengan mencoba semua kemungkinan yang terjadi, dan pengujian dilakukan berulang-ulang. Jika dalam pengujian ditemukan kesalahan, maka akan dilakukan penelusuran dan perbaikan. Jika telah selesai melakukan perbaikan, maka akan dilakukan pengujian kembali. Pengujian dan perbaikan dilakukan secara terus menerus hingga diperoleh hasil yang terbaik. Tabel hasil pengujian sistem dari berbagai kemungkinan proses input yang dilakukan oleh pakar dan pemakai dapat dilihat pada tabel $8,9,10,11$ dan 12 .

\section{a. Permintaan Pick Up Pelanggan}

Tabel 8 Permintaan Pick Up Pelanggan

\begin{tabular}{ll}
\hline \multicolumn{2}{c}{ Kasus Data dan Hasil Uji Coba (Data Salah) } \\
\hline Data Masukan & Nama Penerima : Bayu \\
& Telepon Penerima : \\
& 081122334455 \\
& Alamat Penerima : Malang \\
& Kota Tujuan : Turen, Malang \\
& Lintang: (kosong) \\
& Bujur: (kosong) \\
Yang & Muncul pesan kesalahan \\
Diharapkan & "Gagal, ada isian yang masih \\
& kosong!" \\
Pengamatan & Muncul pesan kesalahan \\
& “Gagal, ada isian yang masih \\
& kosong!" \\
Kesimpulan & Diterima \\
&
\end{tabular}

\begin{tabular}{ll}
\hline Kasus Data dan Hasil Uji Coba (Data Benar) \\
\hline Data Masukan & Nama Penerima : Bayu \\
& Telepon Penerima : \\
& 081122334455 \\
& Alamat Penerima : Malang \\
& Kota Tujuan : Turen, Malang \\
& Lintang: -7.150975 \\
& Bujur : 110.14025939999999 \\
& Data yang dimasukkan benar \\
Yang & lalu menekan tombol selesai \\
Diharapkan & maka akan menampilkan \\
& popup pesan "Sukses, \\
& Permintaan Pick Up \\
& diterima" kemudian kembali \\
& ke tabulasi akun pick up. \\
Pengamatan & menampilkan popup pesan \\
& "Sukses, Permintaan Pick Up \\
& diterima" kemudian kembali \\
& ke tabulasi akun pick up. \\
Kesimpulan & Diterima
\end{tabular}

a. History Pengiriman Pelanggan

Tabel 9 History Pengiriman Pelanggan

\begin{tabular}{ll}
\hline Kasus Data dan Hasil Uji Coba (Data Salah) \\
\hline Data Masukan & $\begin{array}{l}\text { belum login } \\
\text { Yang }\end{array}$ \\
Diharapkan & $\begin{array}{l}\text { Menampilkan tabulasi } \\
\text { riwayat yang tidak ada } \\
\text { card pilihan riwayat. }\end{array}$ \\
Pengamatan & $\begin{array}{l}\text { Menampilkan tabulasi } \\
\text { riwayat yang tidak ada } \\
\text { card pilihan riwayat. }\end{array}$ \\
Kesimpulan & Diterima \\
\hline Kasus Data dan Hasil Uji Coba (Data Benar) \\
\hline Data Masukan & $\begin{array}{l}\text { Login dan memilih tabulasi } \\
\text { data paket yang sudah } \\
\text { diterima. }\end{array}$ \\
Yang & $\begin{array}{l}\text { Menampilkan card data } \\
\text { riwayat paket yang sudah } \\
\text { diterima. }\end{array}$ \\
Piharapkan & $\begin{array}{l}\text { Menampilkan card data } \\
\text { riwayat paket yang sudah } \\
\text { diterima. }\end{array}$ \\
Kesimpulan & Diterima
\end{tabular}

b. Approval Pick Up Kurir

Tabel 10 Approval Pick Up Kurir

\begin{tabular}{cc}
\hline Kasus Data dan Hasil Uji Coba (Data Benar) \\
\hline Data Masukan & $\begin{array}{l}\text { Action (tekan tombol } \\
\text { terima pada data } \text { pick up) }\end{array}$
\end{tabular}




$\begin{array}{ll}\begin{array}{l}\text { Yang } \\ \text { Diharapkan }\end{array} & \begin{array}{l}\text { Muncul pesan kesalahan } \\ \text { "Sukses, anda menerima } \\ \text { permintaan pick up !" }\end{array} \\ \text { Pengamatan } & \begin{array}{l}\text { Muncul pesan kesalahan } \\ \text { "Sukses, anda menerima } \\ \text { permintaan pick up !" }\end{array} \\ \text { Kesimpulan } & \text { Diterima }\end{array}$

c. Transaksi on the Spot

Tabel 11 Transaksi on the Spot

\begin{tabular}{|c|c|}
\hline \multicolumn{2}{|c|}{ Kasus Data dan Hasil Uji Coba (Data Salah) } \\
\hline Data Masukan & $\begin{array}{l}\text { Kota Asal : Wonokromo, } \\
\text { Surabaya } \\
\text { Kota Tujuan : Sukomoro, } \\
\text { Nganjuk } \\
\text { Jenis Barang : (kosong) } \\
\text { Berat Barang : (kosong) }\end{array}$ \\
\hline Yang & Muncul pesan kesalahan \\
\hline Diharapkan & $\begin{array}{l}\text { "Gagal, ada isian yang } \\
\text { masih kosong !" }\end{array}$ \\
\hline Pengamatan & $\begin{array}{l}\text { Muncul pesan kesalahan } \\
\text { "Gagal, ada isian yang } \\
\text { masih kosong!" }\end{array}$ \\
\hline Kesimpulan & Diterima \\
\hline Kasus Data dan & Hasil Uji Coba (Data Benar) \\
\hline Data Masukan & $\begin{array}{l}\text { Kota Asal : Wonokromo, } \\
\text { Surabaya } \\
\text { Kota Tujuan : Sukomoro, } \\
\text { Nganjuk } \\
\text { Jenis Barang : Benda Cair } \\
\text { Berat Barang : } 2\end{array}$ \\
\hline $\begin{array}{l}\text { Yang } \\
\text { Diharapkan }\end{array}$ & $\begin{array}{l}\text { Data yang dimasukkan } \\
\text { benar lalu menekan tombol } \\
\text { selesai maka akan } \\
\text { menampilkan popup pesan } \\
\text { "Berhasil, Transaksi berhasil } \\
\text { dibuat!" kemudian masuk } \\
\text { ke tabulasi operasi. }\end{array}$ \\
\hline Pengamatan & $\begin{array}{l}\text { Menampilkan popup pesan } \\
\text { "Berhasil, Transaksi berhasil } \\
\text { dibuat!" kemudian masuk } \\
\text { ke tabulasi operasi. }\end{array}$ \\
\hline Kesimpulan & Diterima \\
\hline
\end{tabular}

d. History Pengantaran Kurir

Tabel 12 History Pengantaran Kurir

\begin{tabular}{ll}
\hline \multicolumn{2}{c}{ Kasus Data dan Hasil Uji Coba (Data Salah) } \\
\hline Data Masukan & belum login \\
Yang & Menampilkan tabulasi \\
Diharapkan & riwayat yang tidak ada \\
& card pilihan riwayat.
\end{tabular}

$\begin{array}{ll}\text { Pengamatan } & \begin{array}{l}\text { Menampilkan tabulasi } \\ \text { riwayat yang tidak ada } \\ \text { card pilihan riwayat. }\end{array} \\ \text { Kesimpulan } & \text { Diterima }\end{array}$

\begin{tabular}{|c|c|}
\hline \multicolumn{2}{|c|}{ Kasus Data dan Hasil Uji Coba (Data Benar) } \\
\hline Data Masukan & $\begin{array}{l}\text { Login dan memilih } \\
\text { tabulasi data paket yang } \\
\text { pelru diantar. }\end{array}$ \\
\hline Yang & Menampilkan card data \\
\hline Diharapkan & $\begin{array}{l}\text { riwayat paket yang perlu } \\
\text { diantar. }\end{array}$ \\
\hline Pengamatan & $\begin{array}{l}\text { Menampilkan card data } \\
\text { riwayat paket yang perlu } \\
\text { diantar. }\end{array}$ \\
\hline Kesimpulan & Diterima \\
\hline
\end{tabular}

\section{KESIMPULAN}

Berdasarkan implementasi dan pengujian sistem Aplikasi Tracking Paket Ekspedisi CV MK Express, maka dapat disimpulkan bahwa:

a. Aplikasi ini dapat memberikan kemudahan kepada pelanggan untuk melakukan transaksi tanpa harus antri di kantor ekspedisi.

b. Aplikasi ini juga memberikan kemudahan kepada kurir untuk mengetahui lokasi penjemputan barang dan daftar barang yang harus dikirimkan.

c. Proses tracking pada aplikasi ini dapat dilakukan secara realtime karena dideteksi dari perjalanan kurir.

d. Karena proses tracking dilakukan secara realtime maka sistem ini sangat tergantung pada smartphone kurir.

\section{DAFTAR PUSTAKA}

[1] Rachmat, Nufi, dkk. "Tracking Kendaraan Mobil dengan Pemanfaatan GPS (Global Positioning System) Berbasis Android". Jurnal Kajian Ilmiah UBJ, Vol. 15 No. 2, pp.103-1120, September 2015.

[2] Maiyana, Efmi. "Pemanfaatan Android Dalam Perancangan Aplikasi Kumpulan Doa". Jurnal Sains dan Informatika V4 I1, pp 54-65, 2018.

[3] Muri, M. F. Aziz, dkk. "Search Engine Get Application Programming Interface". Jurnal Sains dan Informatika Vol. 5 No. 2, pp. 88-97, November 2019

[4] Wardana, L. Ari. "Perancangan Antarmuka Aplikasi Mobile Konseling Pada Gereja Katolik dengan Metode User Centered Design dan 
Wireframe". S2 thesis, UAJY. 2016.

[5] Kharlampidi, Vladimir. 2018. "Framework 7". [Online]. Available: IEEE Xplore, https : / / framework7.io. [Accessed: 1 Sept. 2010].

[6] Rismayanti and Hasyrif. "Penerapan Tracking Bus "Trans Mamminasata" dengan Memanfaatkan Teknologi Google MAPS API berbasis Mobile Web di Kota Makassar". Jurnal Penelitian Pos dan Informatika Vol. 7 No. 2, pp. 129-142, Desember 2017

[7] Wahyudi, Bambang, dkk. "Rancang Bangun Tracking Mobil Pratoli Berbasis Teknologi GPS dan SMS Gateway". E-Journal SPEKTRUM Vol. 4 No. 1, pp. 49-53, Juni 2017.

[8] Priono, Joko and Eko Budi Setiawan. "Implementasi Geofencing dalam Mengawasi Pengiriman Kendaraan di Sebuah Perusahaan Ekspedisi". Ultimatics, Vol. IX No. 2, pp. 106113, Desember 2017.

[9] Meilani, I. Tri. and Sudaryanto. "Pemodelan Prototype Tracking Dengan Pemanfaatan Geolocation sebagai GPS (Global Positioning System) Berbasis Web Mobile pada Jasa Pengiriman JNE Semarang". Jurnal Techno.Com Vol 15 No. 1, pp. 72-76, Februari 2016

[10] Rini, Tia Hasta dan Intyas, Ilfiyantri. "Perancangan Alat Untuk Tracking Ekspedisi Berbasis GPS (Google Maps) Via SMS". Jurnal ICT Akademi Telkom Jakarta Vol. IX No. 17, pp. 9-18, November 2018.

[11] Y. Purnawan, S. Suhandiah, A. D. Churniawan. "Rancang Bangun Aplikasi Jasa Pengiriman Paket Online Berbasis Android Pada PT Pos Indonesia". Jurnal JSIKA, Vol. 6 No.8, pp. 1-10, 2017.

[12] Pramana, Syafii Ade. "Kantor Ekspedisi Pengiriman di Kota Pontianak". Jurnal Online Mahasiswa Arsitektur Universitas Tanjungpura Vol. 4 No. 2, pp. 129-138, September 2016

[13] Mujianto, H. Ahmad. "Rancang Bangun Sistem Pelaporan Anggaran Dana Bantuan Operasional Sekolah (Bos) Berbasis Web di Dinas Pendidikan Kabupaten Jombang". Jurnal Ilmiah Edutic Vol 2 No.2, pp. 1-9, Mei 2015.

[14] Suendri. "Implementasi Diagram UML (Unified Modelling Language) Pada Perancangan Sistem Informasi Remunerasi Dosen Dengan Database Oracle (Studi Kasus: UIN Sumatera Utara Medan)". Algoritma Volume: 03, Number : 01, pp. 1-9, November 2018.

[15] F. Dhega, I. M. Sudana, and N. Hudallah. "Uji Fungsionalitas (Blackbox Testing) Sistem
Informasi Lembaga Sertifikasi Profesi (SILSP)

Batik dengan Appperfect Web Test dan Uji Pengguna". Joined Jurnal Volume 1, Nomor 2, pp. 117-126, Desember 2018. 